\title{
Derivatives of activated H-ras lacking C-terminal lipid modifications retain transforming ability if targeted to the correct subcellular location
}

\author{
Kristen C Hart² and Daniel J Donoghue ${ }^{1}$ \\ ${ }^{1}$ Department of Chemistry and Biochemistry, Center for Molecular Genetics; ${ }^{2}$ Molecular Pathology Program, School of Medicine, \\ University of California, San Diego, La Jolla, California 92093-0367, USA
}

\begin{abstract}
To examine the ability of ras to activate signal transduction pathways in the absence of lipid modifications, fusion proteins were constructed that target ras $^{\mathrm{wT}}$ or activated ras $^{61 \mathrm{~L}}$ to cellular membranes as integral membrane proteins, using the first transmembrane domain of the $E 1$ protein of avian infectious bronchitis virus (IBV), which contains a cis-Golgi targeting signal. Golgi-targeted derivatives of activated ras were completely inactive in transformation assays. However, when examined in focus formation assays, transformation of NIH3T3 cells were seen with derivatives of ras $^{61 \mathrm{~L}}$ containing a mutated E1 targeting sequence that results in plasma membrane localization. Removal of the lipid modification sites in and upstream of the CAAX motif did not abrogate the transforming activity of plasma membrane-localized ras $^{61 \mathrm{~L}}$ derivatives, indicating that these lipid modifications are not essential for ras activity, as long as the protein is correctly localized to the plasma membrane. Interestingly, the activity of integral membrane versions of ras $^{61 \mathrm{~L}}$ was strictly dependent on a minimum distance between the transmembrane domain anchor region and the coding sequence of ras. Derivatives with only a 3-amino acid linker were inactive, while linkers of either 11- or 22-amino acids were sufficient to restore transforming activity. These results demonstrate that: (1) activated ras targeted to Golgi membranes is unable to cause transformation; (2) lipid modifications at the $\mathrm{C}$-terminus are not required for the transforming activity of plasma membrane-anchored ras $^{61 \mathrm{~L}}$ derivatives, and serve primarily a targeting function; (3) a transmembrane domain can effectively substitute for $\mathrm{C}$-terminal modifications that would normally target ras to the inner surface of the plasma membrane, indicating that ras $^{61 \mathrm{~L}}$ does not need to reversibly dissociate from the membrane as might be allowed by the normal lipidation; and (4) in order to function properly, there exists a critical distance that the ras protein must reside from the plasma membrane.
\end{abstract}

Keywords: ras; subcellular localization; transformation

\section{Introduction}

ras proteins are critical modulators of signaling pathways involved in cell growth and differentiation. p21ras is a member of a large family of small proteins that act as molecular 'switches', cycling between an active GTP-bound state and an inactive GDP-bound

Correspondence: DJ Donoghue

Received 12 August 1996; revised 18 October 1996; accepted 22 October 1996 state (Bourne et al., 1990). ras is activated in response to a wide variety of stimuli, including platelet-derived growth factor (PDGF). Binding of PDGF to its receptors induces their dimerization and transphosphorylation, creating binding sites for effector molecules (reviewed in Hart et al., 1995), some of which regulate or activate ras. Activation of ras by growth factors recruits $R a f-1$ to the plasma membrane (Stokoe et al., 1994; Leevers et al., 1994), leading to Raf-1 activation and subsequent initiation of the MAPK cascade. ras also has been shown to activate Rac and Rho proteins, which control signaling pathways that lead to cytoskeletal modifications (Ridley et al., 1992; Khosravi-Far et al., 1995; Qiu et al., 1995a,b). Activation of this pathway has recently been shown to be crucial for full transformation by ras (Prendergast et al., 1995; Khosravi-Far et al., 1995; Qiu et al., 1995a,b). Thus, combined activation of the Rac/Rho and MAPK pathways may constitute the entire intracellular response necessary for transformation by activated ras.

There are multiple p21 ras proteins, including N-ras, K-ras, and H-ras (reviewed in Santos and Nebreda, 1989; Lowy and Willumsen, 1993), which are localized to the inner surface of the plasma membrane (Willingham et al., 1980; Sefton et al., 1982) through specific sequences in the C-terminus (Willumsen et al., 1984). The mechanism by which ras proteins are targeted to the plasma membrane has been the subject of intense research. Since ras is frequently mutated in tumors, interference with ras localization could become an important means of treating some forms of cancer.

Post-translational modifications of ras proteins occur at the C-terminus, which includes a domain known as the 'CAAX' box, where $\mathrm{A}$ is an aliphatic amino acid, and $X$ represents any amino acid. Processing of this region consists of farnesylation of the conserved Cys residue four amino acids from the C-terminus (Cys186 in H-ras and N-ras), cleavage of the last three amino acids of the protein, and carboxymethylation of the new C-terminal Cys (Hancock et al., 1989; Jackson et al., 1990; Casey et al., 1989; Gutierrez et al., 1989; Clarke et al., 1988; Lowy and Willumsen, 1986; Shih and Weeks, 1984; Willumsen et al., 1984; Sefton et al., 1982). N-ras and Hras have cysteines $\mathrm{N}$-terminal of the CAAX motif, which become palmitoylated after the CAAX processing (Buss and Sefton, 1986). In the case of K-ras-4B, the C-terminus contains a polybasic domain in addition to the CAAX motif which contributes to plasma membrane localization (Hancock et al., 1990, 1991; Jackson et al., 1994). The palmitoylation reactions are reversible, allowing for potentially dynamic localization of ras proteins (Magee et al., 
1987). Although truncation of the C-terminus does not affect the inherent structure or biochemical properties of ras (John et al., 1989), mutations in these motifs render ras proteins cytosolic and inactive, implying that lipid modifications are important for ras function.

There is recent evidence suggesting that the lipid modifications of ras are also necessary for activation of Raf-1 and B-Raf (Okada et al., 1996; Kikuchi and Williams, 1994). However, since these lipid modifications are also responsible for targeting ras to the plasma membrane, it is unclear from these recent reports whether the lipid modifications per se are a necessity, or just localization of ras to the plasma membrane. The palmitoylation reactions that occur in the C-terminus of ras proteins have been shown to be reversible (Magee et al., 1987). There is also some speculation that ras may require reversible association with membranes, and the lipid modifications in the Cterminus provide the potential for this dynamic localization. However, the experimental methods used to date are unable to conclusively distinguish the precise role of lipid modifications in the membrane anchoring and activation of ras.

In order to examine these questions, we have used a novel method of targeting ras to the plasma membrane by creating fusion proteins using the transmembrane targeting signal from the E1 protein of avian IBV placed at the N-terminus (Swift and Machamer, 1991). In its wild-type form, this transmembrane domain is capable of targeting heterologous proteins to cis-Golgi membranes. When the point mutation Gln37 $\rightarrow$ Ile is present, proteins are instead targeted to the plasma membrane. These fusions allow us to address the question of whether ras must be able to reversibly associate with the plasma membrane for biological function as assayed by transformation and GTPase activity. To examine whether C-terminal modifications of ras are required for functions other than targeting, we created similar fusion proteins that contain mutations which abolish processing of the CAAX box. Results presented here demonstrate that ras $^{61 \mathrm{~L}}$ can transform fibroblasts if targeted to the plasma membrane by an N-terminal transmembrane domain, yet is not active when localized to Golgi membranes. We also show that integral membrane versions of $\operatorname{ras}^{61 \mathrm{~L}}$ require a minimum distance from the membrane in order to activate signal transduction pathways leading to transformation.

This work describes the first derivatives of $\mathrm{ras}^{61 \mathrm{~L}}$ that lack any lipid modifications, and demonstrate that $\mathrm{C}$ terminal lipid modifications are not required for transformation by $\operatorname{ras}^{61 \mathrm{~L}}$.

\section{Results}

\section{Description of transmembrane-anchored ras derivatives}

To examine the possibility that activated H-ras can transform if targeted to membranes by an $\mathrm{N}$-terminal transmembrane anchor, a variety of fusion proteins were designed. As illustrated in the left side of Figure 1, $r s^{\mathrm{WT}}$ and $\mathrm{ras}^{61 \mathrm{~L}}$ proteins are localized at the inner surface of the plasma membrane by means of lipid modifications at the $\mathrm{C}$-terminus. The right side of Figure 1 depicts the orientation and design of the

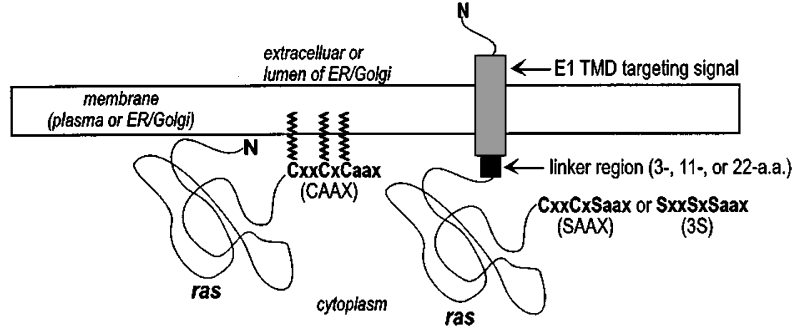

Figure 1 Schematic of ras fusion proteins. All fusion proteins have either the normal C-terminus (amino acids 181-189) of ras $^{\mathrm{WT}}$ or ras $^{61 \mathrm{~L}}$ (CMSCKCVLS), or contain SAAX (CMSCKSVLS) or 3S (SMSSKSVLS) mutations, which alter or abolish the normal post-translational processing and lipid modifications of the proteins. The N-terminus of each E1 derivative is oriented either into the lumen of the Golgi, or is extracellular if the point mutation $\mathrm{Q} \rightarrow \mathrm{I}$ is present. The whole of the ras protein is always cytosolic. The transmembrane domain (designated by the shaded box) is either the cis-Golgi targeting signal contained in the first transmembrane domain of the IBV E1 protein, or a mutated version $(\mathrm{Q} 37 \rightarrow \mathrm{I})$ that targets the protein to the plasma membrane. The linker region between the transmembrane domain and the ras protein denoted by the black box is either 3-, 11-, or 22-amino acids in length

transmembrane-anchored ras derivatives. For derivatives containing the E1 cis-Golgi targeting signal, the transmembrane domain anchors the fusion proteins at Golgi membranes as Type I integral membrane proteins, with the ras-derived portion of the protein still in the cytosol. These derivatives allowed us to examine whether ras could function if localized to any membranous environment, thereby assessing the importance of the interaction between ras and the plasma membrane. Fusion proteins were also designed with a mutated E1(QI) targeting signal and are expected to be transported to the plasma membrane, with the $\mathrm{N}$ terminus outside the cell, and the ras portion of the proteins on the inner surface of the plasma membrane.

Figure 2 represents all of the fusion proteins designed for this study. The feasibility of targeting ras to the plasma membrane by the $\mathrm{N}$-terminus was previously demonstrated in work by Buss et al. (1989) and Lacal et al. (1988), which examined the effect of $\mathrm{N}$ terminal myristylation on $\mathrm{ras}^{61 \mathrm{~L}}$ activity. Buss et al. (1989) described a naturally-occurring myristylated derivative of ras, p29Gag-ras, containing a 59-amino linker region between the myristylated Gly and the ras coding sequence. Lacal and colleagues generated $\mathrm{N}$ terminally anchored ras derivatives by attaching the 15amino acid myristylation signal from pp60c-src. Our derivatives differ in that ras is anchored permanently to membranes as an integral membrane protein. The myristylation targeting signal used in previous studies has the potential to allow reversible association of ras with the plasma membrane. This is an important distinction, which allows us to examine whether ras needs to be able to come off of the membrane in order to function. By exploiting the E1 localization signal, we were also able to target ras specifically to different membranes in the cell. We were also able to examine in more detail the minimum distance from the membrane that ras requires for activity, by designing constructs with linker regions of either 3,11 or 22 amino acids.

Additional fusion proteins were designed to examine the general requirement for lipid modifications for ras activity. ras derivatives with 3 - or 11-amino acid linkers 
were constructed in the context of the unmutated (CAAX) C-terminus, as well as the SAAX and 3S Cterminal mutations. 'CAAX' refers to the wild-type Cterminal sequences of ras. 'SAAX' indicates a mutation of Cys186 in the CAAX motif to Ser, which abolishes the farnesylation, cleavage, and carboxymethylation reactions. ' $3 \mathrm{~S}$ ' refers to mutation of Cys181, 184, and 186 to Ser, which in addition destroys the palmitoylation sites (Hancock et al., 1989). The 22-amino acid linker derivatives were only made in the context of the SAAX mutant C-terminus. Since mutation of all three
C-terminal Cys residues results in a ras protein completely unable to be modified by lipid moieties, these mutants allowed us to assay whether these lipid modifications are necessary for activity, or just utilized in a membrane targeting capacity.

ras derivatives are unable to cause transformation if targeted to Golgi membranes

When tested in focus forming assays, Golgi-targeted derivatives of ras $^{\mathrm{WT}}$ with 3-, 11-, or 22-amino acid

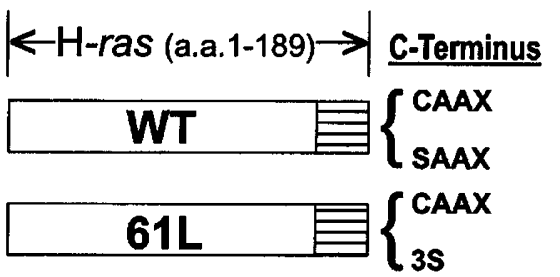

3 a.a. linker

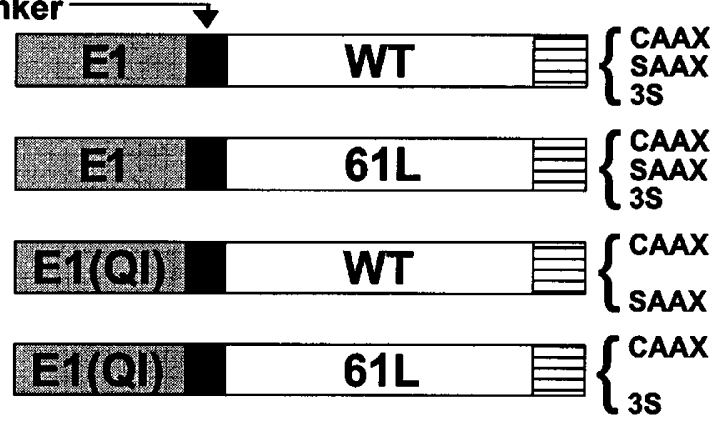

11 a.a. linker $\longrightarrow$
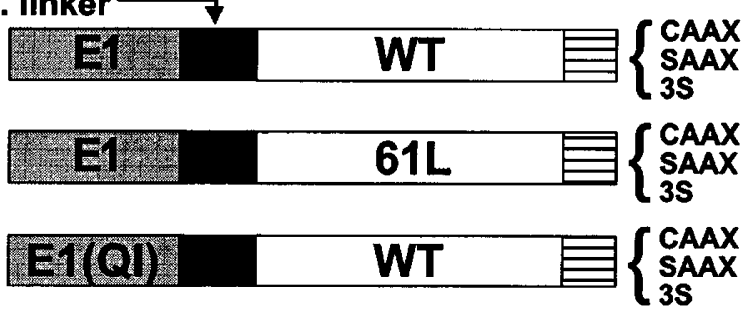

E1(OI)

$61 \mathrm{~L}$

22 a.a. linker

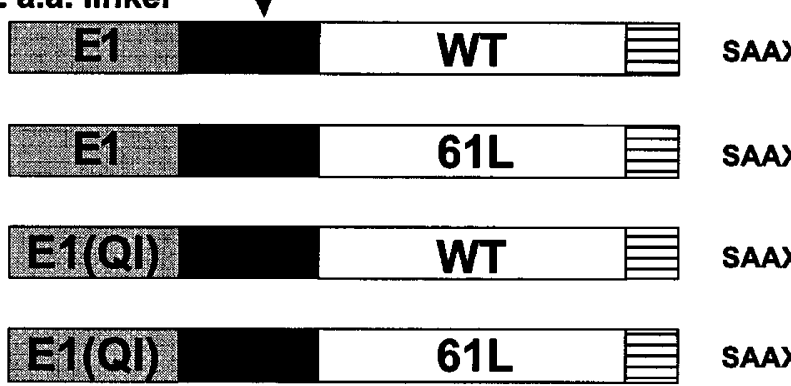

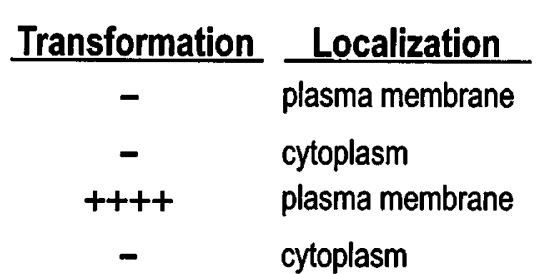

- $\quad$ cytoplasm

$\overline{-}$

ER/Golgi membranes

- $\quad$ ER/Golgi membranes

-

$-$

plasma membrane

plasma membrane

$-$

ER/Golgi membranes

$\overline{-}$

ER/Golgi membranes

-

plasma membrane

$\overline{-}$

$-$

plasma membrane

SAAX

++
++
+++

ER/Golgi membranes

ER/Golgi membranes

plasma membrane

\section{$++++\quad$ plasma membrane}

Figure 2 Localization and transforming activity of ras derivatives. Bars depict the $\operatorname{ras}^{\mathrm{WT}}$ and $\operatorname{ras}^{61 \mathrm{~L}}$ constructs tested in this paper. The following abbreviations are used to describe the different derivatives. '61L' refers to mutation of codon 61 of ras from Gln to Leu, which oncogenically activates the protein (Sekiya et al., 1984). 'El' refers to the first transmembrane domain (amino acids 145) of the E1 protein of avian IBV, which constitutes a cis-Golgi targeting signal that can target heterologous proteins to the Golgi (Swift and Machamer, 1991). 'E1(QI)' indicates a point mutation in the transmembrane domain (Gln37 $\rightarrow$ Ile) that abrogates its Golgi-targeting function, targeting proteins instead to the plasma membrane (Swift and Machamer, 1991). Shaded boxes indicate the E1 or E1(QI) transmembrane domain; black boxes indicate the linker region; striped boxes indicate the C-termini of the clones which is either wild-type (CAAX) or mutant (SAAX or 3S). Localization was determined by indirect immunofluorescence, as described in the legend for Figure 4. Transforming activity of the clones was analyzed in a focus forming assay, where NIH3T3 cells were transfected with the plasmids encoding the fusion proteins, and examined for foci after approximately $12-14$ days. Each experiment was repeated at least three times for transforming derivatives, and at least two times for non-transforming constructs. Results are expressed as an average of all experiments performed with each given construct. $-=0-5 \%$ of $\operatorname{ras}^{61 \mathrm{~L}} ;++=20-25 \%$ of $\operatorname{ras}^{61 \mathrm{~L}} ;+++=50-60 \%$ of ras $^{61 \mathrm{~L}} ;++++=80-100 \%$ of ras $^{61 \mathrm{~L}}$ transforming activity 
linker regions were all inactive. This was expected, since $r a s^{\mathrm{WT}}$ did not induce focus formation in our assays. The Golgi-targeted derivatives of $\operatorname{ras}^{61 \mathrm{~L}}$ were also unable to cause transformation. This was irrespective of whether the linker region was 3-, 11-, or 22-amino acids in length, or whether the C-terminal post-translational modification signals were intact or not.

Figure 4E and I demonstrate localization of E1-11$r a s^{61 \mathrm{~L}}-\mathrm{SAAX}$ and E1-22-ras ${ }^{61 \mathrm{~L}}-\mathrm{SAAX}$, respectively, to a perinuclear region typical of Golgi staining. Panel $\mathrm{K}$ shows the localization of E1-11-ras ${ }^{61 \mathrm{~L}}-\mathrm{CAAX}$, and Figure 4L shows that this fusion protein colocalizes with mAb 10E6 (see arrows), which specifically reacts with a cis-Golgi epitope, and has been used as a marker for the early Golgi (Hart et al., 1994; Wood et al., 1991). This confirms that the Golgi-targeted fusion proteins are localized correctly, and therefore we conclude that $\mathrm{ras}^{61 \mathrm{~L}}$ cannot initiate transforming signal transduction pathways from Golgi membranes, indicating that attachment to any lipid-filled environment is not sufficient for ras to be active.

ras $^{61 \mathrm{~L}}$ derivatives with 11- or 22-amino acid linkers can transform if anchored to the plasma membrane, irrespective of $\mathrm{C}$-terminal lipid modifications

The plasma membrane-targeted derivatives of $r^{6 s^{61 L}}$ with the 3-amino acid linkers (E1(QI)-3-ras ${ }^{61 \mathrm{~L}}-\mathrm{CAAX}$, E1(QI)-3-ras ${ }^{61 \mathrm{~L}}-\mathrm{SAAX}$, and E1(QI)-3-ras $\left.{ }^{61 \mathrm{~L}}-3 \mathrm{~S}\right)$ were all inactive in focus formation assays. However, derivatives with 11- or 22-amino acid linker regions were very active in transformation of NIH3T3 cells. The results of these assays are summarized in Figure 2, which indicates the focus forming activity of each ras derivative as an average of at least three independent experiments. E1(QI)-11-ras ${ }^{61 \mathrm{~L}}-\mathrm{CAAX}, \mathrm{E} 1(\mathrm{QI})-11-r a s^{61 \mathrm{~L}}$ SAAX, E1(QI)-11-ras $s^{61 \mathrm{~L}}-3 \mathrm{~S}$ and E1(QI)-22-ras ${ }^{61 \mathrm{~L}}$ -

(A) mock

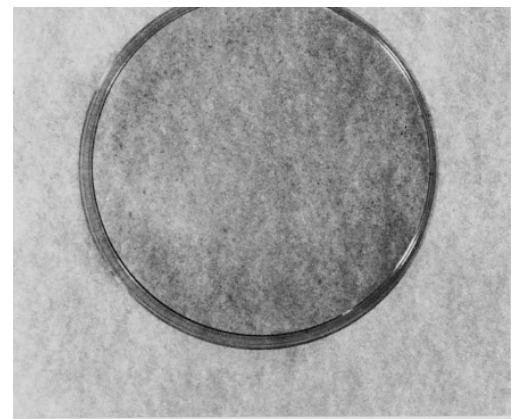

(D) El(QI)-3-ras ${ }^{61 L}-3 S$

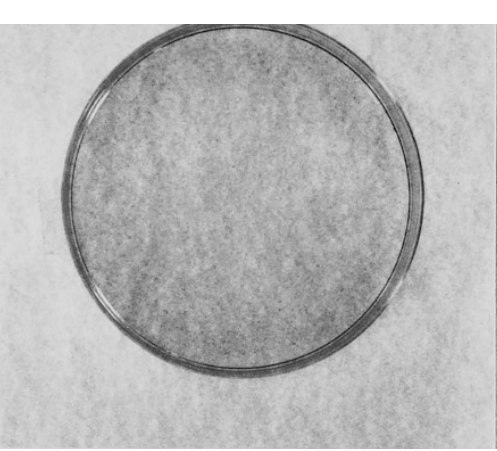

(G) E1(QI)-11-ras ${ }^{61 \mathrm{~L}-3 \mathrm{~S}}$

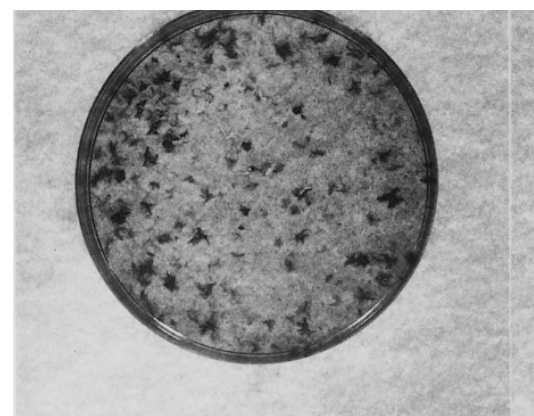

(B) El(QI)-3-ras ${ }^{\text {WT }}$-SAAX

(C) El(QI)-3-ras ${ }^{61 L}$-CAAX

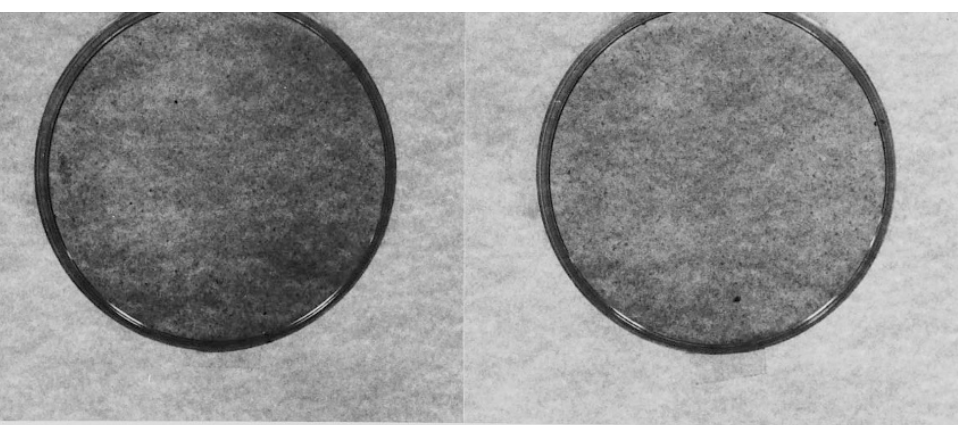

(E) E1(QI)-11-ras ${ }^{61 L_{-}}$CAAX

(F) E1(QI)-11-ras ${ }^{61 L_{-S A A X}}$

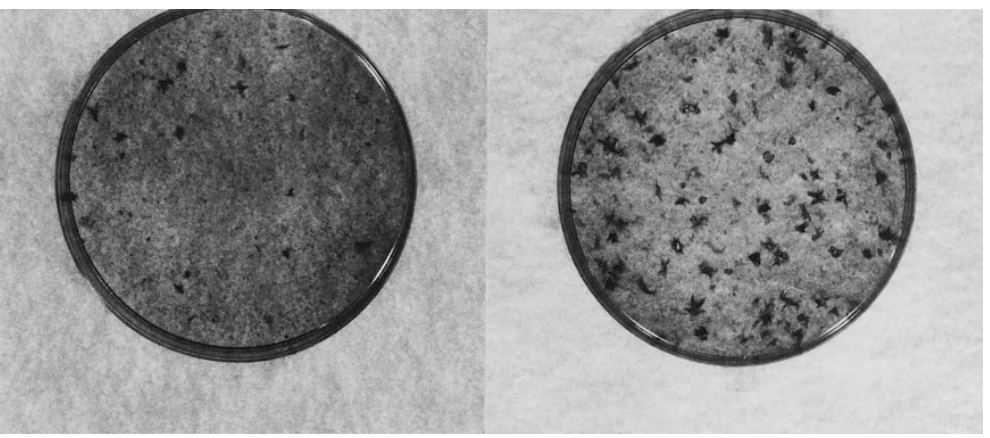

(H) E1(QI)-22-ras ${ }^{61 L}-S A A X$

(I) ras $^{61 L_{-}-C A A X}$
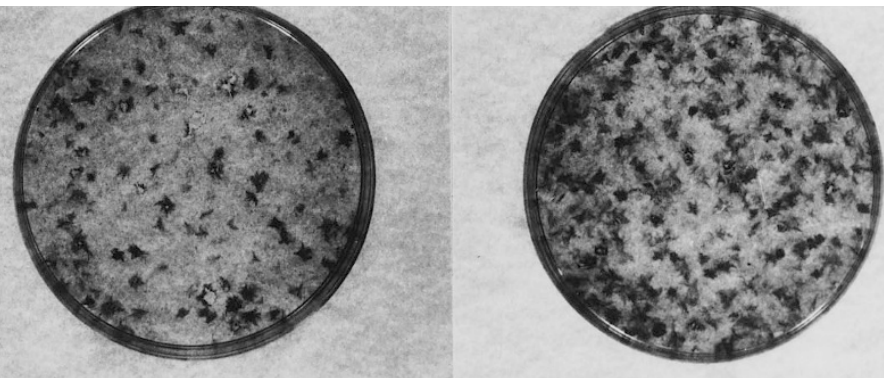

Figure 3 Focus forming assays of ras derivatives targeted to the plasma membrane as integral membrane proteins. Plasmids encoding ras fusion proteins were transfected into NIH3T3 cells, and foci were counted after $12-14$ days. Cells were fixed with methanol, stained with Giemsa, and photographed. (A) mock-transfected cells; (B) E1(QI)-3-ras ${ }^{\mathrm{WT}}$-SAAX; (C) E1(QI)-3-ras ${ }^{61 \mathrm{~L}}$ CAAX; (D) E1(QI)-3-ras ${ }^{61 \mathrm{~L}}$-3S; (E) E1(QI)-11-ras ${ }^{61 \mathrm{~L}}$-CAAX; (F) E1(QI)-11-ras ${ }^{61 \mathrm{~L}}$-SAAX; (G) E1(QI)-11-ras ${ }^{61 \mathrm{~L}}$-3S; (H) E1(QI)-22ras $^{61 \mathrm{~L}}$-SAAX; (I) ras $^{61 \mathrm{~L}}$-CAAX 
SAAX exhibited significant transforming activity in comparison with $\operatorname{ras}^{61 \mathrm{~L}}$ (See Figure $3 \mathrm{E}-\mathrm{I}$ ). It is of interest to note that mutations in the $\mathrm{C}$-terminus of $r s^{61 \mathrm{~L}}$ that abolish the lipidation of the proteins do not affect the ability of activated ras to transform NIH3T3 cells. Indeed, the derivative with an intact $\mathrm{C}$-terminus was consistently three- to four-fold less efficient at transformation than derivatives with mutated Ctermini (See Figure 2; also compare Figure 3E, F and $\mathrm{G})$. This could reflect conformational strains conferred on the protein due to anchoring both termini to the membrane.

Plasma membrane-targeted derivatives containing 3-, 11-, or 22-amino acid linkers were also examined by immunofluorescence. As seen in Figure 4, derivatives that were positive in transformation assays localize to the plasma membrane $(\mathrm{F}, \mathrm{G}, \mathrm{H}$, and $\mathbf{J}$ ), and exhibit staining patterns comparable to that of $\operatorname{ras}^{61 \mathrm{~L}}$ (B). Also, derivatives with 3-amino acid linkers were still targeted to the plasma membrane (D), although unable to transform cells. Thus, derivatives of $\mathrm{ras}^{61 \mathrm{~L}}$ targeted to the plasma membrane via an $\mathrm{N}$-terminal transmembrane domain are able to cause transformation, provided that there is a flexible linker region of sufficient length between the transmembrane anchor and the $\mathrm{N}$-terminus of ras. These results also clearly demonstrate that $\operatorname{ras}^{61 \mathrm{~L}}$ does not require lipid modifications in order to transform cells, and suggests that the C-terminal processing of ras proteins primarily functions in a membraneanchoring capacity.

Immunoprecipitation demonstrates correct expression of fusion proteins

In order to verify that the fusion proteins being expressed were of the correct size, proteins were immunoprecipitated from transiently transfected cells (Figure 5). ras proteins typically run as a doublet on SDS-PAGE gels, one band representing the unprocessed form of ras, the other indicating the mature, processed form of the protein (see arrows) (Shih et al., 1980, 1982). The SAAX and 3 S mutations prevent the C-terminal cleavage step and subsequent lipid modifications from occurring, leaving only a single band (lanes 3 and 4, arrows).

The subtleties of these processing steps are difficult to detect in the remaining fusion proteins shown in Figure 5, due to their increased molecular weight. However, it is quite apparent that all fusion proteins do express the additional $\mathrm{N}$-terminal transmembrane domain sequences (lanes 5-12), and these targeting domains are not cleaved off during maturation of the proteins. The fusion proteins migrate slower than
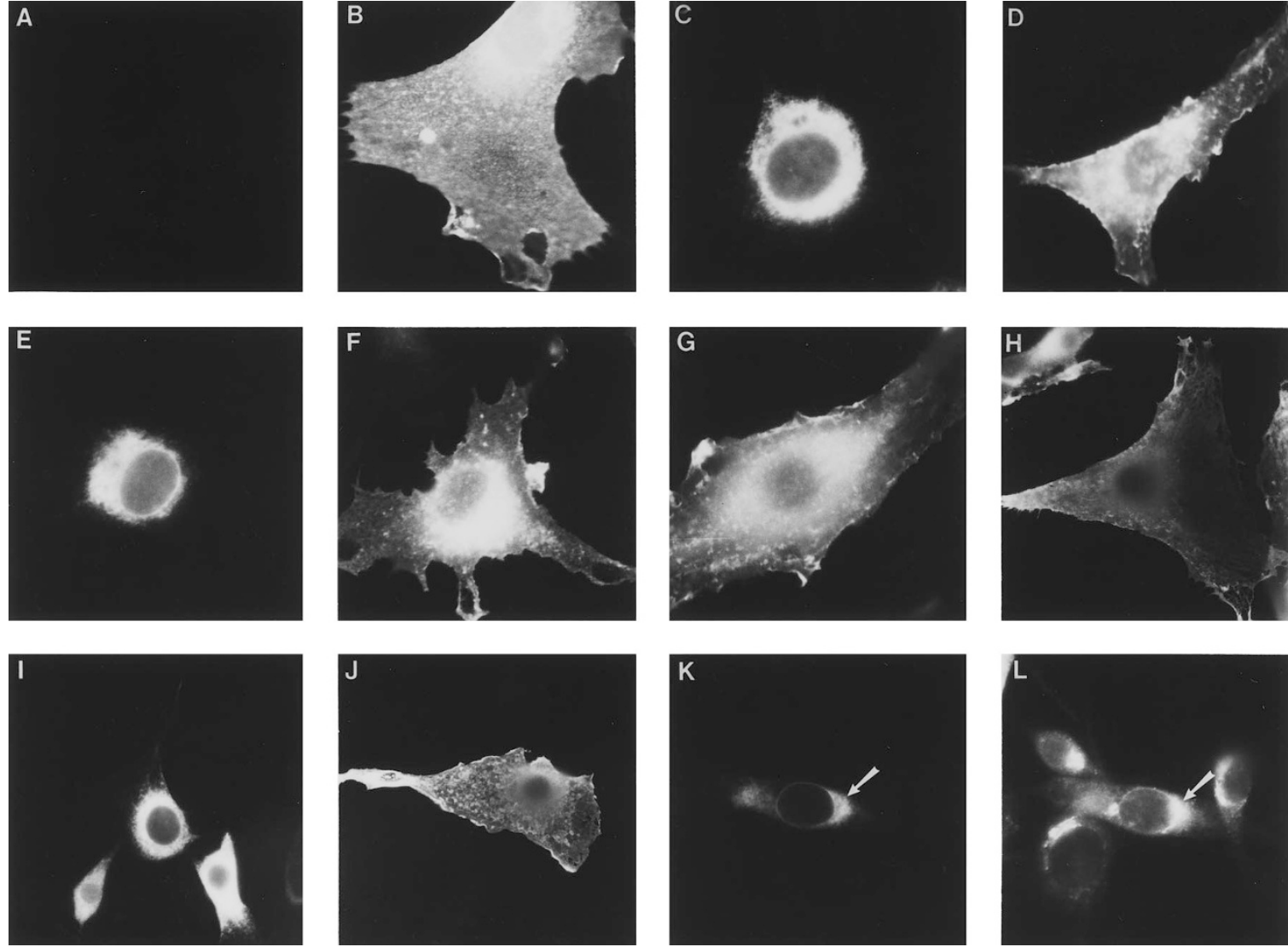

Figure 4 Indirect immunofluorescence confirms localization of ras derivatives. NIH3T3 cells were transiently transfected with various ras constructs, fixed, permeabilized, and incubated with rat mAb Ab-2 (clone Y13-238) and fluorescein-conjugated goat $\alpha$ rat secondary antibody. For (L) mAb 10E6 was used to detect the cis-Golgi, and visualized with rhodamine-conjugated goat $\alpha$ mouse secondary antibody. (A) mock; (B) $\operatorname{ras}^{61 \mathrm{~L}}-\mathrm{CAAX}$; (C) E1-3-ras ${ }^{\mathrm{WT}}-3 \mathrm{~S}$; (D) E1(QI)-3-ras ${ }^{61 \mathrm{~L}}-3 \mathrm{~S}$; (E) E1-11-ras ${ }^{61 \mathrm{~L}}-\mathrm{SAAX}$; (F) E1(QI)-11-ras ${ }^{61 \mathrm{~L}}-\mathrm{CAAX} ;(\mathbf{G})$ E1(QI)-11-ras ${ }^{61 \mathrm{~L}}-\mathrm{SAAX} ;$ (H) E1(QI)-11-ras ${ }^{61 \mathrm{~L}}-3 \mathrm{~S} ;$ (I) E1-22-ras ${ }^{61 \mathrm{~L}}-\mathrm{SAAX}$; (J) E1(QI)-22-ras ${ }^{61 \mathrm{~L}}$ SAAX; (K) E1-11-ras ${ }^{61 \mathrm{~L}}$-CAAX - $\alpha$-ras antibody (fluorescein); (L) E1-11-ras ${ }^{61 \mathrm{~L}}$-CAAX - mAb 10E6 $\alpha$-cis-Golgi antibody (rhodamine). Arrows indicate CAAX - $\mathrm{mAb}$ in $\mathbf{K}$ and $\mathbf{L}$ 


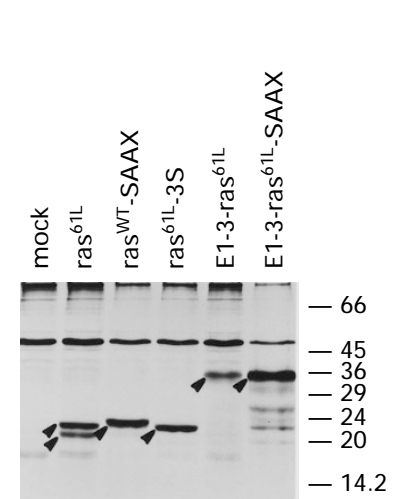

$\begin{array}{llllll}1 & 2 & 3 & 4 & 5 & 6\end{array}$

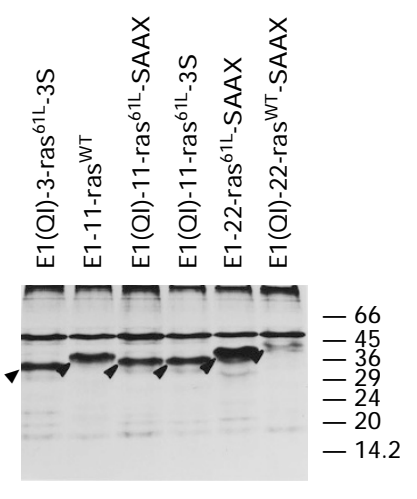

$\begin{array}{llllll}7 & 8 & 9 & 10 & 11 & 12\end{array}$

Figure 5 Immunoprecipitation of ras proteins demonstrates expression of fusion proteins and size differences corresponding to increasing linker length. NIH3T3 cells transiently transfected with various ras derivatives were labeled for $2 \mathrm{~h}$ with $\left.{ }^{35} \mathrm{~S}\right]-\mathrm{Cys}$ and $\left[{ }^{35} \mathrm{~S}\right]-$ Met, lysed, and subjected to immunoprecipitation with $\mathrm{mAb}$ Ab-2 (Y13-238) against v-H-ras. Proteins were separated by $15 \%$ SDS - PAGE, and detected by autoradiography (exposure time $=2$ days) Lane 1: mock; Lane 2: $\operatorname{ras}^{61 \mathrm{~L}}$-CAAX; Lane 3: ras $^{\mathrm{WT}}$-SAAX; Lane 4: $\operatorname{ras}^{6 \mathrm{LL}}$-3S; Lane 5: E1-3-ras ${ }^{61 \mathrm{~L}}$-CAAX; Lane 6: E1-3-ras ${ }^{61 \mathrm{~L}}$-SAAX; Lane 7: E1(QI)-3-ras ${ }^{61 \mathrm{~L}}-3 \mathrm{~S}$; Lane 8: E1-11-ras ${ }^{\mathrm{WT}}$-CAAX; Lane 9: E1(QI)-11-ras ${ }^{61 \mathrm{~L}}$-SAAX; Lane 10: E1(QI)-11-ras ${ }^{61 \mathrm{~L}}-3 \mathrm{~S}$; Lane 11: E1-22-ras ${ }^{61 \mathrm{~L}}$-SAAX; Lane 12: E1(QI)-22-ras ${ }^{\mathrm{WT}}$-SAAX. Molecular weight standards in $\mathrm{kD}$ are indicated to the right of each gel. Arrows indicate position of fusion proteins

expected, which may be due to the presence of an $\mathrm{N}$ linked glycosylation site in the extreme $\mathrm{N}$-terminus of the E1-derived sequence (Machamer et al., 1990).

\section{GTPase activity of transmembrane-anchored ras derivatives}

The transforming ability of some of the plasma membrane-targeted derivatives of $\mathrm{ras}^{61 \mathrm{~L}}$ indicates that their function was not adversely affected by addition of an N-terminal transmembrane domain. To analyse whether fusion proteins that were non-transforming were still able to function in some manner, GTPase activity was examined. ras $^{61 \mathrm{~L}}$ remains locked in the GTP-bound state longer due to a decreased rate of GTP hydrolysis (Temeles et al., 1985), despite a 50-fold increased binding affinity for rasGAP (Krengel et al., 1990). If the N-terminal transmembrane domain does not interfere with normal protein function, one would expect to see a higher GTPase activity exhibited by ras $^{\mathrm{WT}}$ fusion proteins, as compared to ras $^{61 \mathrm{~L}}$ derivatives. Using thin-layer chromatography, this difference in GTPase activities is apparent, as shown by a higher proportion of labeled GDP versus GTP in $\mathrm{ras}^{\mathrm{WT}}$ samples as compared to ras ${ }^{61 \mathrm{~L}}$ samples (Figure 6, lanes 1 and 2).

Interestingly, $\operatorname{ras}^{61 \mathrm{~L}}$ with the $3 \mathrm{~S}$ mutation in the $\mathrm{C}$ terminus, which renders the protein cytosolic and inactive in transformation, does not affect the GTPase activity (lane 3). Derivatives of $\operatorname{ras}^{\mathrm{WT}}$ with the 3-amino acid linker hydrolyze GTP, irrespective of whether they are targeted to the plasma membrane (lane 5) or Golgi membranes (lane 4). ras $^{61 \mathrm{~L}}$ derivatives with transmembrane anchors and 3-amino acid linkers exhibit impaired GTPase activity as expected (data not shown). Finally, the 11- and 22-amino acid derivatives of $\operatorname{ras}^{\mathrm{WT}}$ (lanes 6 and 8) or $\mathrm{ras}^{61 \mathrm{~L}}$ (lanes 7 and 9) exhibit

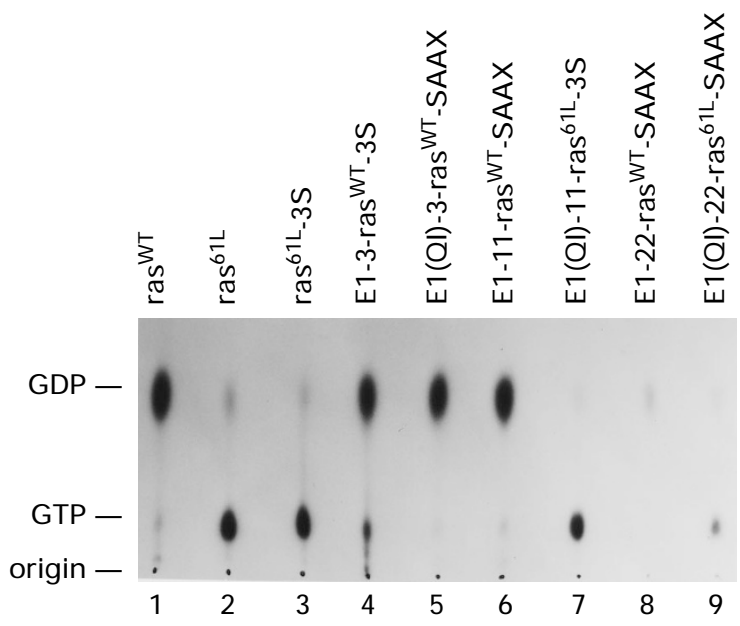

Figure 6 GTPase activity of transmembrane-anchored ras derivatives. Fusion proteins were immunoprecipitated with $\mathrm{mAb}$ Ab-2 (Y13-238) from transiently transfected NIH3T3 cells, and subjected to an in vitro GTPase assay with $\alpha-\left[{ }^{32}\right.$ P $]$ GTP. Samples were spotted on PEI-Cellulose plates and chromatographed in $0.75 \mathrm{M} \mathrm{KH}_{2} \mathrm{PO}_{4}, \mathrm{pH}$ 3.4. Locations of GTP and GDP are indicated at the left of the figure. Note that all ras ${ }^{\mathrm{WT}}$ derivatives have a higher GTPase activity (lanes 1, 4, 5,6 and 8) compared to ras $^{61 \mathrm{~L}}$ derivatives (lanes 2, 3, 7 and 9), as evidenced by increased amount of labeled GDP versus GTP in $\operatorname{ras}^{\mathrm{WT}}$ samples. This result is irrespective of localization to Golgi or plasma membranes, and regardless of C-terminal modifications. Lane 1: $\operatorname{ras}^{\mathrm{WT}}$-CAAX; Lane 2: ras $^{61 \mathrm{~L}}-\mathrm{CAAX}$; Lane 3: $\operatorname{ras}^{61 \mathrm{~L}}-3 \mathrm{~S}$; Lane 4: E1-3-ras ${ }^{\mathrm{WT}}-3 \mathrm{~S}$; Lane 5: E1(QI)-3-ras ${ }^{\mathrm{WT}}$-SAAX; Lane 6: E1-11-ras ${ }^{\mathrm{WT}}$-SAAX; Lane 7: E1(QI)-11-ras ${ }^{61 \mathrm{~L}}-3 \mathrm{~S}$; Lane 8: E1-22-ras ${ }^{\mathrm{WT}}$-SAAX; Lane 9: E1(QI)-22-ras ${ }^{61 \mathrm{~L}}$-SAAX

the expected GTPase activity profiles, regardless of the transmembrane domain attached at the N-terminus or the modifications present at the C-terminus. These results demonstrate that ras proteins can be targeted to the plasma membrane via a transmembrane anchor without affecting the expected GTPase activity of the proteins. Also, we find that C-terminal lipid modifications do not play a role in maintaining the intrinsic GTPase activity of wild-type or activated ras.

\section{Discussion}

\section{C-terminal lipid modifications are not required for ras $^{61 L}$} transforming activity

The experiments described above demonstrate that $r s^{61 \mathrm{~L}}$ can activate transforming signal transduction pathways when targeted by the N-terminus to the plasma membrane as an integral membrane protein. This activity was completely independent of the normal post-translational processing that occurs at the C-terminus of ras proteins. Since $\operatorname{ras}^{61 \mathrm{~L}}$ derivatives (E1(QI)-11-ras $s^{61 \mathrm{~L}}-\mathrm{SAAX}, \quad \mathrm{E} 1(\mathrm{QI})-11-r a s^{61 \mathrm{~L}}-3 \mathrm{~S}$ and E1(QI)-22-ras ${ }^{61 \mathrm{~L}}$-SAAX) lacking the C-terminal sequences required for normal processing of ras are still able to cause transformation, it is clear that lipid modifications per se are not required for activity of oncogenic ras. This is the first demonstration of nonlipidated transforming derivatives of ras.

Our data suggests that post-translational modification of H-ras serves primarily to target the protein to the plasma membrane. Whether there are other, more subtle functions of these $\mathrm{C}$-terminal lipid modifications 
distinct from their more obvious targeting function remains to be demonstrated. The observation that three of the transmembrane-anchored derivatives, E1(QI)-11-ras ${ }^{61 \mathrm{~L}}-\mathrm{SAAX}, \quad \mathrm{E} 1(\mathrm{QI})-11-r a s^{61 \mathrm{~L}}-3 \mathrm{~S}, \quad$ and E1(QI)-22-ras ${ }^{61 \mathrm{~L}}-\mathrm{SAAX}$, retain transforming activity despite their inability to be lipid-modified strongly implies that downstream signaling molecules such as Raf-1 and the MAPK cascade are activated in these cells. This contradicts recent reports that posttranslational modifications of ras are required for activation of $R a f-1$ and B-Raf (Okada et al., 1996; Kikuchi and Williams, 1994). The precise activation state of effectors downstream from ras, and whether these molecules are activated in a similar fashion by integral membrane versions of ras, is currently under investigation.

Transforming activity of transmembrane derivatives of ras demonstrates that ras does not require transient or reversible association with the membrane

If the lipid modifications on ras proteins serve only a targeting function, as indicated by our results, this raises the question of why ras proteins evolved to contain C-terminal lipid modifications instead of a more permanent transmembrane anchor. Small GTPbinding proteins related to ras are now known to function in a variety of capacities within the cell, such as mediating vesicular transport in the process of endocytosis, sorting and trafficking through the secretory pathway, and regulating the structure of the cytoskeleton (reviewed in Hall, 1994; FerroNovick and Novick, 1993; Pfeffer, 1994; Zerial and Stenmark, 1993). Some of these processes may require the regulatory GTP-binding proteins to be transiently or reversibly associated with lipid bilayers, and only lipid modifications would allow this dynamic association to occur. Our results suggest, in the case of ras, that a reversible association with the plasma membrane is not required for activation of transforming signal transduction pathways, since integral membrane versions of ras $^{61 \mathrm{~L}}$ are transforming. It would be interesting to examine the effects of anchoring other small GTP-binding proteins more permanently to specific membranes or compartments using targeting sequences such as the transmembrane domain from the E1 protein.

ras proteins require a minimum spacing from the plasma membrane in order to function

Transforming activity of ras $^{61 \mathrm{~L}}$ derivatives was dependent upon a minimum distance from the plasma membrane mediated by the length of the linker region. Altering the distance between ras and the plasma membrane does affect the ability of ras to activate signal transduction pathways, as demonstrated by the inactivity of 3 -amino acid linker derivatives of ras $^{61 \mathrm{~L}}$ and activation of these derivatives in transformation assays by addition of 11- or 22-amino acid linker regions. The crystal structure of c-H-ras bound to GDP (residues 1-171) or GTP (residues 1-166) indicates that the extreme C-terminus forms an alpha-helical region that juts out from the globular catalytic region of ras (De Vos et al., 1988; Pai et al., 1989), suggesting that the catalytic domain is well- removed from the membrane in normal ras proteins. One can imagine that the native C-terminus of ras constitutes a natural 'linker' region, not unlike the artificial linker regions incorporated into our ras fusion proteins. This would explain the failure of the short 3amino acid linker at the N-terminus to allow for a functional fusion protein, whereas linkers of 11- or 22amino acids, corresponding more closely in length to the C-terminus of normal ras, do result in a transforming $\operatorname{ras}^{61 \mathrm{~L}}$ derivative.

Conformational energy analysis performed on the 18 C-terminal amino acids excluded from the crystal structure of the GDP-bound form of ras indicates that this region likely forms a helix-turn-helix or 'helical hairpin' motif, allowing the $\mathrm{N}$-terminus and C-terminus of ras to be in close proximity (BrandtRauf et al., 1990). Perhaps these two regions of the protein interact in some manner. However, it appears from our results that interactions between the $\mathrm{N}$ terminus and lipid modifications at the $\mathrm{C}$-terminus are not important for ras function. There could be one or more effectors of ras that bind to a site different from the identified effector domain, and access to this site may be dependent upon orientation of the protein with respect to the membrane, or may require binding to sites at both the $\mathrm{N}$ - and $\mathrm{C}$ terminus of ras proteins. Identification of other membrane-associated factors involved in regulation or activation of ras proteins and their effectors will provide clues as to why ras proteins evolved their unique structural elements.

\section{GTPase activity of ras derivatives}

Clearly the intrinsic GTPase activities of our fusion proteins are not altered when compared to normal versions of $\operatorname{ras}^{\mathrm{WT}}$ and $\mathrm{ras}^{61 \mathrm{~L}}$. GTP binding and hydrolysis are also apparently unaffected by mutation of the CAAX box. Thus, it appears that neither the $\mathrm{N}$ - nor the C-terminus are important for this function of ras. Specific amino acids in the effector regions of ras (amino acids $32-38$ or Switch $\mathrm{I}$, and amino acids $60-76$ or Switch II) are involved in association with guanine nucleotides and also in binding to regulators of GTPase and nucleotide exchange activities. Since GTPase activity is normal in the fusion proteins, the overall structure of the catalytic regions is not expected to be drastically altered. To our knowledge, this is the first study examining the role of C-terminal lipid modifications in regulating GTPase activity of ras.

One discrepancy between our results and those of Buss et al. (1989) is that anchoring of wild-type ras to the plasma membrane by the E1(QI) transmembrane domain does not result in transformation. Buss et al. (1989) found significant focus forming ability of wildtype ras after addition of $\mathrm{N}$-terminal myristylation. They speculated that perhaps their protein was binding to inappropriate cellular targets, which may not be promoted by a transmembrane anchor. It is also possible that interaction with nucleotide exchange factors was enhanced in myristylated $\operatorname{ras}^{\mathrm{WT}}$ derivatives, but this does not occur in E1(QI)-ras ${ }^{\mathrm{WT}}$ constructs. To further clarify the role of membrane association in regulating the inherent enzymatic activity of ras proteins, it would be interesting to see if there 
are any subtle effects on the association of integral membrane versions of ras proteins with regulators of GTPase and nucleotide exchange activities.

\section{Implications for regulation and activation of ras}

The observation that Golgi-targeted derivatives of ras are unable to transform fibroblasts, while perhaps not unexpected, provides some insight into the requirements for signal transduction through the ras pathway. It is clear that some mediators of the transforming pathway initiated by oncogenic ras are only available at the plasma membrane. Precisely what these mediators are remains to be elucidated. However, one can conclude that simple juxtaposition of ras to a lipidrich environment is not sufficient to allow it to signal. Examination of these Golgi-targeted ras derivatives and their ability to interact with or activate the normal cytosolic substrates such as Raf-1 will provide future insights into the function of ras.

Recent evidence demonstrates that other important pathways regulating cytoskeletal structure and organization are also activated by ras. Rac1 regulates membrane ruffling in response to growth factor stimulation (Ridley et al., 1992), while RhoA functions in the regulation of actin stress fiber and focal adhesion assembly in growth factor-stimulated cells (Ridley and Hall, 1992). It appears that activation of both the MAPK and Rac/Rho pathways is required for full transformation by ras (Prendergast et al., 1995; Khosravi-Far et al., 1995; Qiu et al., 1995a,b). In light of this recent evidence, we are currently investigating activation of the $\mathrm{Rac} / \mathrm{Rho}$ pathway in response to our integral membrane versions of ras.

\section{Materials and methods}

\section{Construction of fusion proteins}

Full-length Harvey p21 ras ${ }^{\mathrm{wT}}$ and p21 $\mathrm{ras}^{61 \mathrm{~L}}$ cloned into pcDNAI at the HindIII-EcoRI sites were generously provided by $\mathbf{J}$ Buss. Restriction sites in the coding sequences of $\mathrm{ras}^{\mathrm{WT}}$ and $\mathrm{ras}^{61 \mathrm{~L}}$ used to make these clones are as follows: BsaHI at nt 28 and FspI at nt 215 were used in generation of clones with E1 or E1(QI) transmembrane anchors; AfIIII at nt 470 was utilized to generate mutations in the $\mathrm{C}$-terminus. Note that the mutation resulting in the Gln $\rightarrow$ Leu at codon 61 occurs at nt 182 , and consists of a $\mathrm{A} \rightarrow \mathrm{T}$ transversion. All constructs containing $\mathrm{N}$-terminal transmembrane domains and/or C-terminal mutations described in this paper were constructed using the following strategy. Pairs of complementary oligonucleotides were designed and synthesized such that, when annealed, overhangs for restriction sites were formed. More details about the making of the various fusion constructs are available upon request. All synthetic oligonucleotides were gel purified as previously described (Xu et al., 1993), and all DNA sequences derived from oligonucleotides were confirmed by dideoxy nucleotide sequencing before use.

\section{Focus assays}

NIH3T3 cells were maintained as previously described (Hart et al., 1994). Cells were split at a density of $2 \times 10^{5}$ cells per $60 \mathrm{~mm}$ plate and transfected the following day using the calcium phosphate precipitation protocol (Chen and Okayama, 1987). Cells from each $60 \mathrm{~mm}$ plate were split
1:12 2 days later, and scored for foci $12-14$ days later. These assays were repeated at least $2 \times$ for each construct.

\section{Indirect immunofluorescence}

NIH3T3 cells were split $1 \times 10^{5}$ onto $60 \mathrm{~mm}$ plates containing glass coverslips and transfected the following day with $10 \mu \mathrm{g}$ of plasmid DNA, as described above. Two days after transfection, the cells were fixed with $3 \%$ paraformaldehyde/PBS and permeabilized with $0.5 \%$ Triton X-100/PBS. The intracellular location of ras fusion proteins was detected with rat monoclonal antiserum Ab-2 (Y13-238) directed against v-H-ras (Oncogene Science) and fluorescein-conjugated goat $\alpha$-rat secondary antibody (Boehringer Mannheim).

For double-labeling experiments, cells were fixed and permeabilized as described above. ras fusion proteins were detected as described above, then the coverslips were treated with monoclonal Ab 10E6, which detects the cis-Golgi of cells (kindly provided by WJ Brown and V Malhotra) and rhodamine-conjugated goat $\alpha$-mouse secondary antibody (Boehringer Mannheim).

\section{Immunoprecipitation}

NIH3T3 cells were split $2 \times 10^{5}$ onto $60 \mathrm{~mm}$ plates and 2 days after transfection, monolayers were washed $2 \times$ with Tris-saline, incubated $15 \mathrm{~min}$ with DME minus Cys and Met, and then labeled for $2 \mathrm{~h}$ with $100 \mu \mathrm{Ci}$ each of $\left[{ }^{35} \mathrm{~S}\right]-$ Cys and $\left.{ }^{35} \mathrm{~S}\right]-$ Met. Cells were lysed in RIPA (1\% Triton X$100,0.15 \mathrm{M} \mathrm{NaCl}, 50 \mathrm{~mm}$ Tris- $\mathrm{HCl} \mathrm{pH} 7.5,0.1 \%$ SDS, $1 \%$ DOC, $10 \mu \mathrm{g} / \mathrm{ml}$ aprotinin), precleared with Protein ASepharose, and incubated with Ab-2 rat monoclonal antibody. Immunoprecipitates were collected with Protein A-Sepharose beads coated with rabbit $\alpha$-rat $\mathrm{IgG}$, washed $4 \times$ with RIPA, and resuspended in $2 \times$ sample buffer $(50 \mathrm{~mm}$ Tris $\mathrm{pH} 6.8,2 \%$ SDS, 20\% 2-mercaptoethanol, $10 \%$ glycerol). Proteins were separated by $15 \%$ SDSPAGE and detected by fluorography.

\section{GTPase assays}

NIH3T3 cells were transfected as described for immunoprecipitation. Two days after transfection, monolayers were lysed with lysis buffer $(20 \mathrm{~mm}$ Tris- $\mathrm{HCl}$ pH 7.5, $0.125 \mathrm{M} \mathrm{NaCl}, 1 \mathrm{~mm} \mathrm{MgCl}, 1 \mathrm{mM} \mathrm{CaCl}, 1 \%$ Triton X$100,10 \mu \mathrm{g} / \mathrm{ml}$ aprotinin) and precleared with Protein ASepharose. One third of the total lysate was then subjected to immunoprecipitation using Ab-2. Immune complexes were collected on Protein A-Sepharose beads coated with rabbit $\alpha$-rat IgG, washed $2 \times$ with lysis buffer, $2 \times$ with RIPA, then incubated for $30 \mathrm{~min}$ on ice with $100 \mu \mathrm{l}$ of $1.0 \times 10^{-7} \mathrm{M} \alpha-\left[{ }^{32} \mathrm{P}\right] \mathrm{GTP}$ in RIPA. Beads were then washed $3 \times$ with RIPA, $1 \times$ with lysis buffer, and incubated at $37^{\circ} \mathrm{C}$ for $1 \mathrm{~h}$ in $100 \mu \mathrm{l}$ of lysis buffer. $2 \mu \mathrm{l}$ of each sample was spotted onto PEI-cellulose plates (JT Baker, Phillipsburg, New Jersey) and chromatographed in $0.75 \mathrm{M}$ $\mathrm{KH}_{2} \mathrm{PO}_{4}, \mathrm{pH} 3.4$.

\section{Abbreviations}

E1, avian coronavirus E1 glycoprotein; ER, endoplasmic reticulum; IBV, infectious bronchitis virus.

\section{Acknowledgements}

We thank Jan Buss for providing the p21ras ${ }^{\mathrm{WT}}$ and p21 $\operatorname{ras}^{61 \mathrm{~L}}$ plasmids that served as the starting point for construction of all clones described in this paper, and for helpful advice on GTPase assays. We thank WJ Brown and $\mathrm{V}$ Malhotra for the mAb 10E6 used for co-localization studies. We also thank April Meyer for technical support, 
Melanie Webster and Patricia d'Avis for critical reading of the manuscript, and Laura Castrejon for editorial assistance. $\mathrm{KCH}$ would like to thank Scott Robertson, Ryan Dellinger, and Vincent Ollendorff for advice and support. $\mathrm{KCH}$ gratefully acknowledges support from the Lucille $\mathrm{P}$

\section{References}

Bourne HR, Sanders DA and McCormick F. (1990). Nature, 348, $125-132$.

Brandt-Rauf PW, Carty RP, Chen JM, Lee G, Rackovsky S and Pincus MR. (1990). J. Prot. Chem., 9, 137-142.

Buss JE and Sefton BM. (1986). Mol. Cell. Biol., 6, 116-122.

Buss JE, Solski PA, Schaeffer JP, MacDonald MJ and Der CJ. (1989). Science, 243, 1600-1603.

Casey PJ, Solski PA, Der CJ and Buss JE. (1989). Proc. Natl. Acad. Sci. USA, 86, 8323-8327.

Chen C and Okayama H. (1987). Mol. Cell. Biol., 7, 27452752.

Clarke S, Vogel JP, Deschenes RJ and Stock J. (1988). Proc. Natl. Acad. Sci. USA, 85, 4643-4647.

De Vos AM, Tong L, Milburn MV, Matias PM, Jancarik J, Noguchi S, Nishimura S, Miura K, Ohtsuka E and Kim SH. (1988). Science, 239, $888-893$.

Ferro-Novick S and Novick P. (1993). Ann. Rev. Cell Biol., 9, $575-599$.

Gutierrez L, Magee AI, Marshall CJ and Hancock JF. (1989). EMBO J., 8, $1093-1098$.

Hall A. (1994). Ann. Rev. Cell Biol., 10, 31-54.

Hancock JF, Cadwallader K, Paterson H and Marshall CJ. (1991). EMBO J., 10, 4033-4039.

Hancock JF, Magee AI, Childs JE and Marshall CJ. (1989). Cell, 57, $1167-1177$.

Hancock JF, Paterson H and Marshall CJ. (1990). Cell, 63, $133-139$.

Hart KC, Galvin BD and Donoghue DJ. (1995). Genet. Eng. NY., 17, 181-208.

Hart KC, Xu Y-F, Meyer AN, Lee BA and Donoghue DJ. (1994). J. Cell Biol., 127, 1843-1857.

Jackson JH, Cochrane CG, Bourne JR, Solski PA, Buss JE and Der CJ. (1990). Proc. Natl. Acad. Sci. USA, 87, $3042-$ 3046.

Jackson JH, Li JW, Buss JE, Der CJ and Cochrane CG. (1994). Proc. Natl. Acad. Sci. USA, 91, 12730-12734.

John J, Schlichting I, Schiltz E, Rosch P and Wittinghofer A. (1989). J. Biol. Chem., 264, 13086-13092.

Khosravi-Far R, Solski PA, Clark GJ, Kinch MS and Der CJ. (1995). Mol. Cell. Biol., 15, 6443-6453.

Kikuchi A and Williams LT. (1994).. J. Biol. Chem., 269, 20054-20059.

Krengel U, Schlichting L, Scherer A, Schumann R, Frech M, John J, Kabsch W, Pai EF and Wittinghofer A. (1990). Cell, 62, 539- 548 .

Lacal PM, Pennington CY and Lacal JC. (1988). Oncogene, 2, 533- 537.

Leevers SJ, Paterson HF and Marshall CJ. (1994). Nature, 369, $411-414$

Lowy DR and Willumsen BM. (1986). Cancer Surveys, 5, $275-289$
Markey Charitable Trust. This work was supported by grant 3RT-0242 from the U.C. Tobacco Related Disease Research Program and by grant CB-163 from the American Cancer Society.

Lowy DR and Willumsen BM. (1993). Ann. Rev. Biochem., 62, $851-891$.

Machamer CE, Mentone SA, Rose JK and Farquhar MG. (1990). Proc. Natl. Acad. Sci. USA, 87, 6944-6948.

Magee AI, Gutierrez L, McKay IA, Marshall CJ and Hall A. (1987). EMBO J., 6, 3353-3357.

Okada T, Masuda T, Shinkai M, Kariya K and Kataoka T. (1996). J. Biol. Chem., 271, 4671-4678.

Pai EF, Kabsch W, Krengel U, Holmes KC, John J and Wittinghofer A. (1989). Nature, 341, 209-214.

Pfeffer SR. (1994). Curr. Opin. Cell Biol., 6, 522-526.

Prendergast GC, Khosravi-Far R, Solski PA, Kurzawa H, Lebowitz PF and Der CJ. (1995). Oncogene, 10, 22892296.

Qiu RG, Chen J, Kirn D, McCormick F and Symons M. (1995a). Nature, 374, 457-459.

Qiu RG, Chen J, McCormick F and Symons M. (1995b). Proc. Natl. Acad. Sci. USA, 92, 11781-11785.

Ridley AJ and Hall A. (1992). Cell, 70, 389-399.

Ridley AJ, Paterson HF, Johnston CL, Diekmann D and Hall A. (1992). Cell, 70, $401-410$

Santos E and Nebreda AR. (1989). FASEB J., 3, 2151-2163.

Sefton BM, Trowbridge IS, Cooper JA and Scolnick EM. (1982). Cell, 31, 465-474.

Sekiya T, Fushimi M, Hori H, Hirohashi S, Nishimura S and Sugimura T. (1984). Proc. Natl. Acad. Sci. USA, 81, $4771-4775$.

Shih TY, Papageorge AG, Stokes PE, Weeks MO and Scolnick EM. (1980). Nature, 287, 686-691.

Shih TY and Weeks MO. (1984). Cancer Investigation, 2 , $109-123$.

Shih TY, Weeks MO, Gruss P, Dhar R, Oroszlan S and Scolnick EM. (1982). J. Virol., 42, 253-261.

Stokoe D, Macdonald SG, Cadwallader K, Symons M and Hancock JF. (1994). Science, 264, 1463 - 1467.

Swift AM and Machamer CE. (1991). J. Cell Biol., 115, $19-$ 30.

Temeles GL, Gibbs JB, D'Alonzo JS, Sigal IS and Scolnick EM. (1985). Nature, 313, 700-703.

Willingham MC, Pastan I, Shih TY and Scolnick EM. (1980). Cell, 19, $1005-1014$.

Willumsen BM, Christensen A, Hubbert NL, Papageorge AG and Lowy DR. (1984). Nature, 310, 583-586.

Wood SA, Park JE and Brown WJ. (1991). Cell, 67, $591-$ 600.

Xu Y-F, Meyer AN, Webster MK, Lee BA and Donoghue DJ. (1993). J. Cell Biol., 123, 549-560.

Zerial M and Stenmark H. (1993). Rab GTPases in vesicular transport. Current Opin. Cell Biol., 5, 613-620. 